\title{
EFFECT OF AMYGDALOID LESIONS ON PLASMA AND PITUITARY LEVELS OF LUTEINIZING HORMONE*
}

\author{
B. E. ELEFTHERIOU AND A. J. ZOLOVICK \\ Department of Zoology, Kansas State University, Manhattan
}

(Received 19th April 1966)

\begin{abstract}
Summary. Lesions were made by electrocoagulation in the basolateral amygdaloid group in female deermice, $P$. m. bairdii. Levels of luteinizing hormone in the plasma increased significantly and levels of LH in the pituitary decreased in animals with lesions. The plasma level of LH 3 weeks after lesioning was $31 \%$ higher than that during oestrus, at which the highest levels occur. The tentative conclusion is reached that the basolateral amygdaloid complex may, under normal conditions, exert an inhibitory effect on the pituitary secretion of $\mathrm{LH}$.
\end{abstract}

\section{INTRODUCTION}

The role of the hypothalamus in the regulation of pituitary hormonal secretion is well documented. However, our knowledge of regulation of hormonal secretion by the amygdaloid complex is indeed very limited (Mason, 1959; Bovard \& Gloor, 1959; Setekleiev, Skoug \& Kaada, 1961; Mason, Nauta, Brady \& Robinson, 1961; Kovacs, Sandor, Vertes \& Vertes, 1965); although extensive research has been conducted on the effects of lesions and electrical stimulation of the amygdala on a number of behavioural phenomena (Thompson \& Walker, 1950, 1951; Walker, Thompson \& McQueen, 1953; Brady, Schreiner, Geller \& Kling, 1954; Green, Clemente \& De Groot, 1957; Masserman, Levitt, McAvoy, Kling \& Pechtel, 1958; Elwers \& Critchlow, 1960; Orbach, Milner \& Rasmussen, 1960; Kling \& Schwartz, 1961).

This work deals with the effects of lesions in the basolateral amygdaloid group on plasma and pituitary levels of luteinizing hormone in the female deermouse (Peromyscus maniculatus bairdii).

\section{MATERIALS AND METHODS}

Adult female deermice (Peromyscus maniculatus bairdii) weighing 15 to $19 \mathrm{~g}$ were anaesthetized with sodium pentobarbitol, oriented in a stereotaxic instrument, and bilaterally lesioned in the basolateral nuclear group of the amygdaloid complex according to the stereotaxic atlas for this species (Eleftheriou \& Zolo-

* Publication No. 405 of Zoology series and No. 392 from the Department of Zoology, Kansas Agricultural Experiment Station, Manhattan. 
vick, 1965). Lesions were produced by electrocoagulation using a High Frequency Hyfrecator discharging $1.5 \mathrm{~mA}$ of current for $7 \mathrm{sec}$ through a monopolar varnish-coated stainless steel electrode. Insulation was removed $0.3 \mathrm{~mm}$ from the tip to produce a lesion of uniform diameter. A large stainless-steel bar, inserted in the anus, served as the indifferent electrode. Following the operation, the mice were isolated one per cage and daily vaginal smears were taken from these and control animals.

Non-lesioned controls were killed in three groups of seven at di-oestrus, pro-oestrus and oestrus of the oestrous cycle; groups of seven lesioned animals were killed 1, 2 and 3 weeks after the operation. In addition, three groups of seven animals each, in which the electrode penetrated the amygdala without administration of current (sham operated), were killed at 2 weeks. Blood was collected in heparinized syringes by entering the orbital sinus of the eye. Plasma samples were obtained by centrifugation at $1000 \mathrm{~g}$ for $15 \mathrm{~min}$ and frozen for later analyses. Pituitaries were removed, weighed to the nearest $0.1 \mathrm{mg}$ and frozen in saline.

Position of lesions was confirmed by histological examination of formalinfixed brains stained with Cresyl Violet Blue.

Pituitary and plasma levels of luteinizing hormone (LH) were estimated by the ovarian ascorbic acid depletion method (Parlow, 1961). Immature rats, 55 to $60 \mathrm{~g}$, of the Holtzman strain, served as the receptor animals for the pituitary homogenate and plasma. One millilitre of pituitary homogenate from each group of seven female bairdii ( $1 \mathrm{mg} / \mathrm{ml}$ in saline) was injected in groups of four recipient animals whereas $0.6 \mathrm{ml}$ of plasma was injected in two animals. In addition, saline, I, 5, 10 and $20 \mu \mathrm{g}$ of NIH-S-5 ovine standard LH was injected in four recipient animals each to establish a standard LH-regression curve. Pituitary and plasma levels of $\mathbf{L H}$ were calculated from a standard log curve derived from the following equation: $Y=67.656-27.552 \log X$, where $Y$ is OAA $\mathrm{mg} / 100 \mathrm{ml}$ and $X$ is $\mu \mathrm{g}$ of LH. The values for $\mathrm{LH}$ were transformed then into milliunits of $\mathrm{LH} / \mathrm{mg}$ of pituitary tissue or of plasma. Analysis of variance was used to test significance of $\mathbf{L H}$ values.

\section{RESULTS}

The locations of the lesions were confirmed by histological examination to be in the basolateral amygdaloid complex (Text-fig. 1).

Results of daily vaginal smears indicated that all lesioned animals went into di-oestrus immediately after lesioning and remained in this phase throughout the 21-day period of this experiment.

During the oestrous cycle, plasma levels of $\mathrm{LH}$ increased significantly $(P<0 \cdot 01)$ from a di-oestrus value of 0.82 to an oestrus level of 2.0 milliunits $/ \mathrm{ml}$ (Text-fig. 2). In this period, pituitary levels of $\mathbf{L H}$ decreased from a di-oestrus level of 0.61 to an oestrus level of 0.06 milliunits/mg of pituitary tissue. These values for plasma and pituitary levels, when corrected to milliunits/pituitary/animal, and the reciprocal relationship of pituitary to plasma levels are consistent with previous findings in the rat (Maric, Matsuyama \& Lloyd, 1965; Schwartz \& Caldarelli, 1965). 


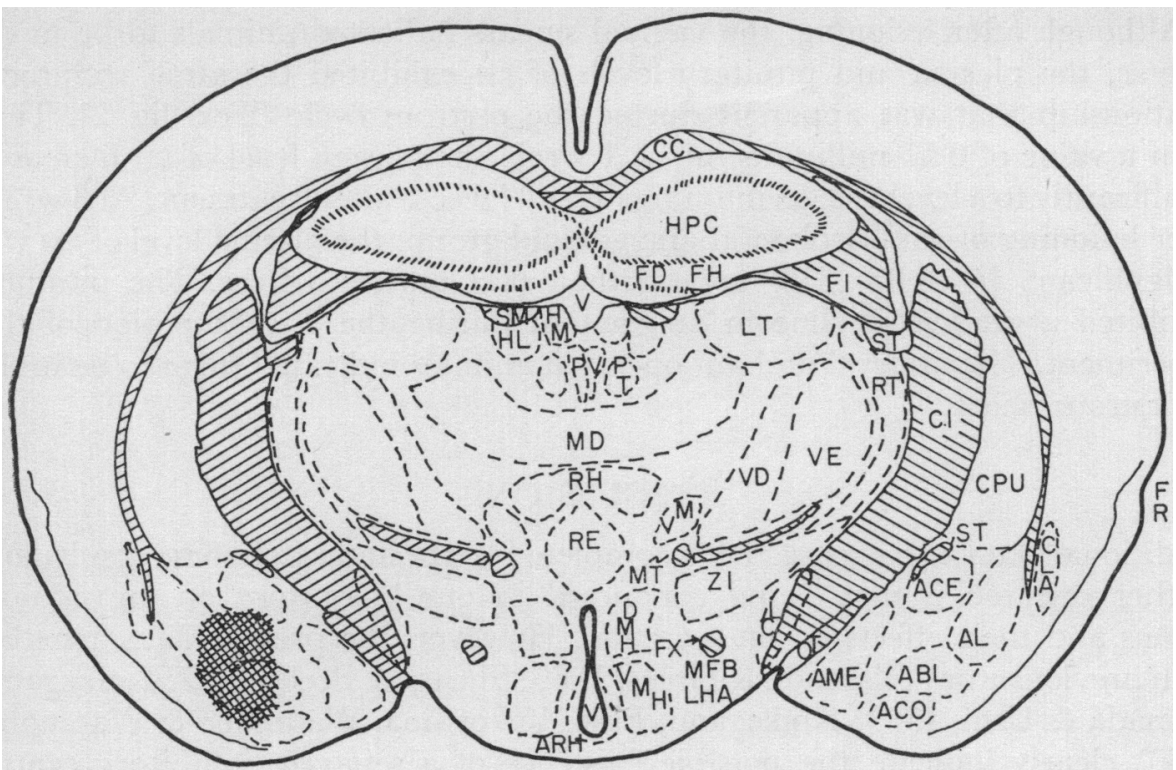

TEXT-FIG. 1. Diagrammatic representation of the brain of $P$. $m$. bairdii. The cross-hatched area in left hemisphere represents the area in which all lesions were localized. In the right hemisphere the location of various nuclei are indicated. $\mathbf{A B L}=$ basolateral nucleus; $\mathrm{AME}=$ medial amygdaloid nucleus; $\mathrm{ACE}=$ central amygdaloid nucleus; $\mathrm{AL}=$ lateral amygdaloid nucleus; $\mathrm{ACO}=$ cortical amygdaloid nucleus.
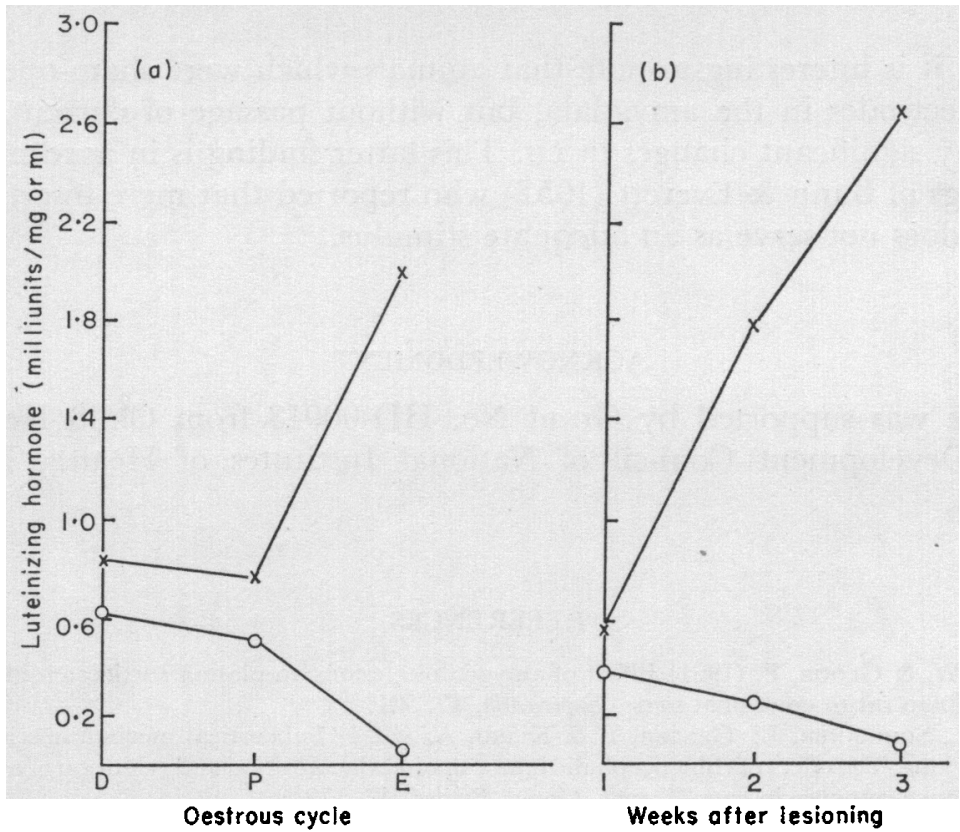

TEXT-FIG. 2. Plasma $(X)$ and pituitary $(O)$ levels of luteinizing hormone (in milliunits/ $\mathrm{mg}$ or $\mathrm{ml}$ ) during three phases of: (a) oestrous cycle, and (b) during 3 weeks after lesions of the basolateral amygdaloid group. 
Although after lesioning, the vaginal smears indicated animals to be in dioestrus, the plasma and pituitary levels of LH exhibited the same reciprocal relationship that was apparent during the oestrous cycle (Text-fig. 2). Thus from a value of 0.51 milliunits $/ \mathrm{ml}$, at 1 week, the plasma level of $\mathrm{LH}$ increased significantly to a level of 2.63 milliunits $/ \mathrm{ml}$ at 3 weeks after treatment. At 3 weeks after lesioning of the basolateral amygdaloid group, the plasma level of $\mathrm{LH}_{\mathrm{H}}$ was a significant $(P<0.01) 31 \%$ greater than that during oestrus. The pituitary exhibited a gradual decline in LH content during the 3-week period of this experiment. The LH level of sham-operated animals indicated them to be in the di-oestrous phase.

\section{DISCUSSION}

Additional data are necessary for complete interpretation of these results and further research is now being conducted in our laboratory on amygdaloid lesions and their effects on LH secretion. However, the present data, together with previous work (Yamada \& Greer, 1960; Shealy \& Peele, 1957; Koikegami, Yamada \& Usui, 1953; Koikegami, Fuse, Yokoyama, Watanobe \& Watanobe, 1955) clearly indicate the possible existence of a separate inhibitory centre, in this species, for the regulation of luteinizing hormone.

The possibility also exists that injury from lesions produces a focal point of irritation which may be the starting point of potentials that spread to other areas of the brain, and mainly to the hypothalamus (Taleisnik, Caligaris \& DeOlmos, 1962) for the release of LH. But, in our opinion, it seems unlikely that such an irritation would produce sustained secretion of LH over a period of 3 weeks.

Finally, it is interesting to note that animals which were sham-operated by placing electrodes in the amygdala, but without passage of current, did not exhibit any significant changes in LH. This latter finding is in agreement with the findings of Bunn \& Everett (1957) who reported that mere insertion of an electrode does not serve as an adequate stimulus.

\section{ACKNOWLEDGMENT}

This work was supported by Grant No. HD-00013 from Child Health and Human Development Council of National Institutes of Health, Bethesda, Maryland.

\section{REFERENGES}

Bovard, E. W. \& Gloor, P. (1961) Effect of amygdaloid lesions on plasma corticosteroid response of the albino rat to emotional stress. Experientia, 17, 521.

Brady, J. V., Schreiner, L. Geller, I. \& Kling, A. (1954) Subcortical mechanisms in emotional behaviour: The effect of rhinencephalic injury upon the acquisition and retention of a conditioned avoidance response in cats. F. comp. physiol. Psychol. 47, 179.

Bunn, J. P. \& Everetr, J. W. (1957) Ovulation in persistent-estrous rats after electrical stimulation of the brain. Proc. Soc. exp. Biol. Med. 96, 369.

Eleftheriou, B. E. \& Zolovick, A. J. (1965) The forebrain of the deermouse in stereotaxic coordinates. Tech. Bull. Kans. agric. Exp. Stn, 146. 
Elwers, M. \& Critchlow, V. (1960) Precocious ovarian stimulation following hypothalamic and amygdaloid lesions in rats. Am. F. Physiol. 198, 381.

Green, J. D., Clemente, C. D. \& DeGroot, J. (1957) Rhinencephalic lesions and behaviour in cats. F. comp. Neurol. 108, 505.

King, A. \& Schwartz, N. (1961) Effects of amygdalectomy on feeding in infant and adult animals. (Abstract). Fedn Proc. Fedn Am. Socs exp. Biol. 20, 335.

KoIkegami, H., Yamada, T. \& Usur, K. (1953) Stimulation of amygdaloid nuclei and periamygdaloid cortex with special reference to its effects on uterine movements and ovulation. Folia psychiat. neurol. jap. 8, 7.

Koikegami, H., Fuse, S., Yokoyama, T., Watanobe, T. \& Watanobe, H. (1955) Contribution to the comparative anatomy of the amygdaloid nuclei of mammals with some experiments of their destruction or stimulation. Folia psychiat. neurol jap. 8, 336 .

Kovacs, S., Sandor, A., Vertes, Z. \& Vertes, M. (1965) The effect of lesions and stimulation of the amygdala on pituitary-thyroid function. Acta physiol. hung. 27, 221.

Maric, D. K., Matsuyama, E. \& Lloyd, C. W. (1965) Gonadotropin content of pituitaries of rats in constant estrus induced by continuous illumination. Endocrinology, 77, 529 .

Mason, J. W. (1959) Plasma 17-hydroxycorticosteroid levels during electrical stimulation in amygdaloid complex in conscious monkeys. Am. F. Physiol. 196, 44.

Mason, J. W., Nauta, W. J., Brady, J. V. \& Robinson, J. A. (1959) Limbic system influences on the pituitary-adrenal cortical system. 41st Meeting, Endocrine Society, Atlantic City Program, p. 29 (Abstract).

Masserman, J. H., Levitt, M., McAvoy, T., Kling, A. \& Pechtel, C. (1958) The amygdalae and behavior. Am. F. Psychiat. 115, 14.

Orbach, J., Milner, B. \& Rasmussen, T. (1960) Learning and retention in monkeys after amygdalahippocampus resection. Arch. Neurol. 3, 230.

Parlow, A. F. (1961) Bioassay of pituitary luteinizing hormone by depletion of ovarian ascorbic acid. In: Human Pituitary Gonadotropin, p. 300. Ed. A. Albert. Thomas, Springfield, Illinois.

Schwartz, N. B. \& Caldarelli, D. (1965) Plasma LH in cyclic female rats. Proc. Soc. exp. Biol. Med. $119,16$.

Setekleiev, J., Sxoug, O. E. \& KaAda, B. R. (1961) Plasma hydroxycorticosteroids and amygdaloid lesions. F. Endocr. 22, 119.

Shealy, N. C. \& Peele, T. L. (1957) Studies on amygdaloid nucleus of the cat. F. Neurophysiol. 20, 125.

Taleisnik, S., Caligaris, L. \& DeOlmos, J. (1962) Luteinizing hormone release by cerebral cortex stimulation in rats. Am. J. Physiol. 203, 1109.

Thompson, A. F. \& WALker, A. E. (1950) Behavioral alterations following lesions of the medial surface of the temporal lobe. Folia psychiat. neurol. neurochir. neerl. 53, 444.

Thompson, A. F. \& WALKER, A. E. (1951) Behavioral alterations following lesions of the medial surface of the temporal lobe. Archs Neurol. Psychiat. 65, 251.

Walker, A. E., Thompson, A. F. \& McQueEN, J. D. (1953) Behavior and the temporal rhinencephalon in the monkey. Fohns Hopkins Hosp. Bull. 93, 65.

Yamada, T. \& GReER, M. A. (1960) The effect of bilateral ablation of the amygdala on endocrine function in the rat. Endocrinology, 66, 565 . 